The University of Akron

\title{
IdeaExchange@UAkron
}

Proceedings from the Document Academy

University of Akron Press Managed

December 2014

\section{Documenting the Information-seeking Experience of Remedial Undergraduate Students}

Shelley Blundell

Kent State University - Kent Campus, sblundel@kent.edu

Please take a moment to share how this work helps you through this survey. Your feedback will be important as we plan further development of our repository.

Follow this and additional works at: https://ideaexchange.uakron.edu/docam

Part of the Educational Methods Commons, Higher Education Commons, and the Information Literacy Commons

\section{Recommended Citation}

Blundell, Shelley (2014) "Documenting the Information-seeking Experience of Remedial Undergraduate Students," Proceedings from the Document Academy: Vol. 1 : Iss. 1 , Article 4.

DOI: https://doi.org/10.35492/docam/1/1/4

Available at: https://ideaexchange.uakron.edu/docam/vol1/iss1/4

This Conference Proceeding is brought to you for free and open access by University of Akron Press Managed at IdeaExchange@UAkron, the institutional repository of The University of Akron in Akron, Ohio, USA. It has been accepted for inclusion in Proceedings from the Document Academy by an authorized administrator of

IdeaExchange@UAkron.For more information, please contact mjon@uakron.edu, uapress@uakron.edu. 


\section{Introduction}

During the spring of 2014, I engaged in a qualitative study which sought to examine, describe, and document the information-seeking experience of undergraduate students enrolled in a remedial English course at a 4-year, state university in Ohio, in the United States of America. Previously, I had observed there was a significant gap in the library and information science literature regarding the academic information needs and seeking behaviors of remedial undergraduate students (defined as undergraduate students who require remedial coursework in subjects such as math, English, and college-level study before they can enter traditional higher education coursework). Therefore, I undertook the study for my dissertation research with the intention of contributing to the slim body of knowledge available. Although secondary data analysis is still inprogress, I presented my initial findings, based on primary analysis of the collected data, at the $11^{\text {th }}$ annual meeting of the Document Academy (DOCAM'14) in Kent, Ohio, on August 9, 2014, toward soliciting feedback from attendees and discussing the need for further research in this understudied area before an international audience of scholars.

This proceedings paper includes a background to and rationale for the study described above, a theoretical model of the academic information search process of Millennial undergraduate students (which I created based on a thorough review of literature and research available in this area), initial findings from primary analysis of collected data, next steps in the study, and concluding thoughts, as presented at DOCAM'14.

\section{Background to the Study}

In the spring of 2013, I and Dr. Frank Lambert, a professor in the School of Library and Information Science at Kent State University in Kent, Ohio, conducted an exploratory investigation into the self-reported information anxiety of undergraduate students enrolled in both traditional and remedial English courses at a 4-year, state university in Ohio. Respondents were asked to complete the 'Information Anxiety Scale,' which adapted Sharon Bostick's Library Anxiety Scale (Onwuegbuzie, Jiao, \& Bostick, 2004) by adding items to the scale specifically related to information technology usage and comprehension, toward understanding which elements related to libraries and information technology usage registered the most anxiety for respondents. Unfortunately, the response rate from students in remedial English courses was too low for scientific analysis, so results were analyzed from students in the traditional English courses only. However, findings were nonetheless quite interesting in terms of differences 
between sex and race, and a full report of these findings may be found in the Journal of Education in Library and Information Science (publication forthcoming). Related to the study I undertook for my dissertation, notable findings from the information anxiety study include: a) $47.8 \%$ of respondents agreed or strongly agreed they were unsure about how to begin their research, b) $62.5 \%$ of respondents agreed or strongly agreed they feel uncomfortable searching for information, and c) $67 \%$ of respondents agreed or strongly agreed they do not want to learn how to do their own research (Blundell \& Lambert, 2014).

As evidenced by the results of this study, there is a need to further investigate the information seeking behaviors of undergraduate students, particularly those enrolled in remedial English courses, from whom data could not be interpreted for the study described above due to low response rates. How these findings factor into the scholarly literature on the subject shall be discussed in the next section of this paper.

\section{Rationale for the Study}

Based on a broad review of the scholarly literature in the field of undergraduate student information seeking behaviors in preparation for my dissertation research, I prepared the following summative statements as a rationale for my proposed study.

Today's undergraduates:

- Encounter numerous problems when searching for information to meet academic needs (e.g. an assigned research paper), including "getting started" (Project Information Literacy, 2012), which $84 \%$ of respondents to a national, cross-university study stated was the most difficult part of research (Project Information Literacy, 2012; Head, 2013);

- Many undergraduate students have limited information literacy skills, but often overestimate their skills in this area, and do not recognize the authority of others to provide them with the ability to develop these skills or assist them in their academic endeavors (Gross \& Latham, 2011; 2009; 2007; Gross, 2005);

- Many undergraduate students experience academically limiting information anxiety, which directly and negatively affects their academic progress (Blundell \& Lambert, 2014; Jerabek, Meyer \& Kordinak, 2001; Jiao \& Onwuegbuzie, 2004; Jiao, Onwuegbuzie \& Lichtenstein, 1996; Kalbach, 2006; Kuhlthau, 1991; Kwon, 2008; 
Kwon, Onwuegbuzie \& Alexander, 2007; Lee, 2012; Malvasi, Rudowsky \& Valencia, 2009; Nahl \& Bilal, 2007; Nicholas, Huntington, Jamali, Rowlands \& Fieldhouse, 2009; O'Brien \& Symons, 2007; Onwuegbuzie, Jiao \& Bostick, 2004; Prabha, Connaway, Olszewski \& Jenkins, 2007; Van Kampen, 2004; Vitasari, Wahab, Ochman \& Awang, 2010); and

- Undergraduate students with remedial education needs, who account for more than a quarter of all incoming undergraduate students in 4year state universities in Ohio, experience all of the issues and problems described above at a much greater level, and have higher rates of course failure and institutional attrition than their non-remedial peers (Bailey, Jaggars \& Scott-Clayton, 2013; Bettinger \& Long, 2005; Buglear, 2009; DiTommaso, 2012; Hamilton, 2013; Mulvey, 2009; Parker, 2012; Roselle, 2009; Sparks \& Malkus, 2013).

Based on the research regarding the information-seeking behaviors of traditional undergraduate students, many studies found that a person's understanding and possession of information literacy skills (the ability to "recognize when information is needed and have the ability to locate, evaluate, and use effectively the needed information" [American Library Association, 2000]) is innately linked to their ability to create and follow through with a balanced and appropriate academic information search process (Boon, Johnston, \& Webber, 2007). Additionally, as Salisbury and Karasmanis (2011) assert, information literacy skills are "intertwined" (p. 43) with learning in general. Therefore, I believe there is a definite need to learn more about the specific information seeking behaviors of remedial undergraduate students, so that targeted information literacy instruction can be created that addresses their needs specifically and supports their academic progress.

It is worth noting that previous research in the area of undergraduate information literacy instruction (ILI) posits that the most effective type of instruction is collaborative (i.e. involving collaboration between faculty members and librarians). However, the faculty member leading the course in which my dissertation study was conducted chose not to collaborate with a librarian when offering ILI, and it was therefore imperative for me to see the type of ILI students received prior to engaging in information seeking for a specific academic assignment (i.e. a research paper). The level of depth these observations added to the study and to a broader understanding of the information-seeking experience of participants was invaluable, and contributed greatly to the rationale for providing more research in the area of the information-seeking behaviors of undergraduate students in remedial coursework. 
Presented next in this paper is a theoretical model of the academic information search process of the Millennial undergraduate student. How and why this model was created is described within the next section.

\section{Theoretical Model of the AISP of the Millennial Undergraduate Student}

I created this model as a visual summary of the literature I reviewed on the academic information search process of traditional undergraduate students. The theoretical model of the academic information search process (AISP) of the Millennial undergraduate student represents commonalities found across the literature regarding this process, as it is enacted by students in response to course requirements, such as the completion of a research paper. In addition, this model constitutes a 'bracketing' exercise within my dissertation study, a necessary component of descriptive phenomenological study, which is conducted prior to and during data collection (Dowling, 2007; Englander, 2012; Giorgi, 1997; van Manen, 1990; Wojnar \& Swanson, 2007). Stages of the AISP included in the model are presented below the model itself. 


\section{Image 1: The theoretical model of the AISP of the Millennial undergraduate student}

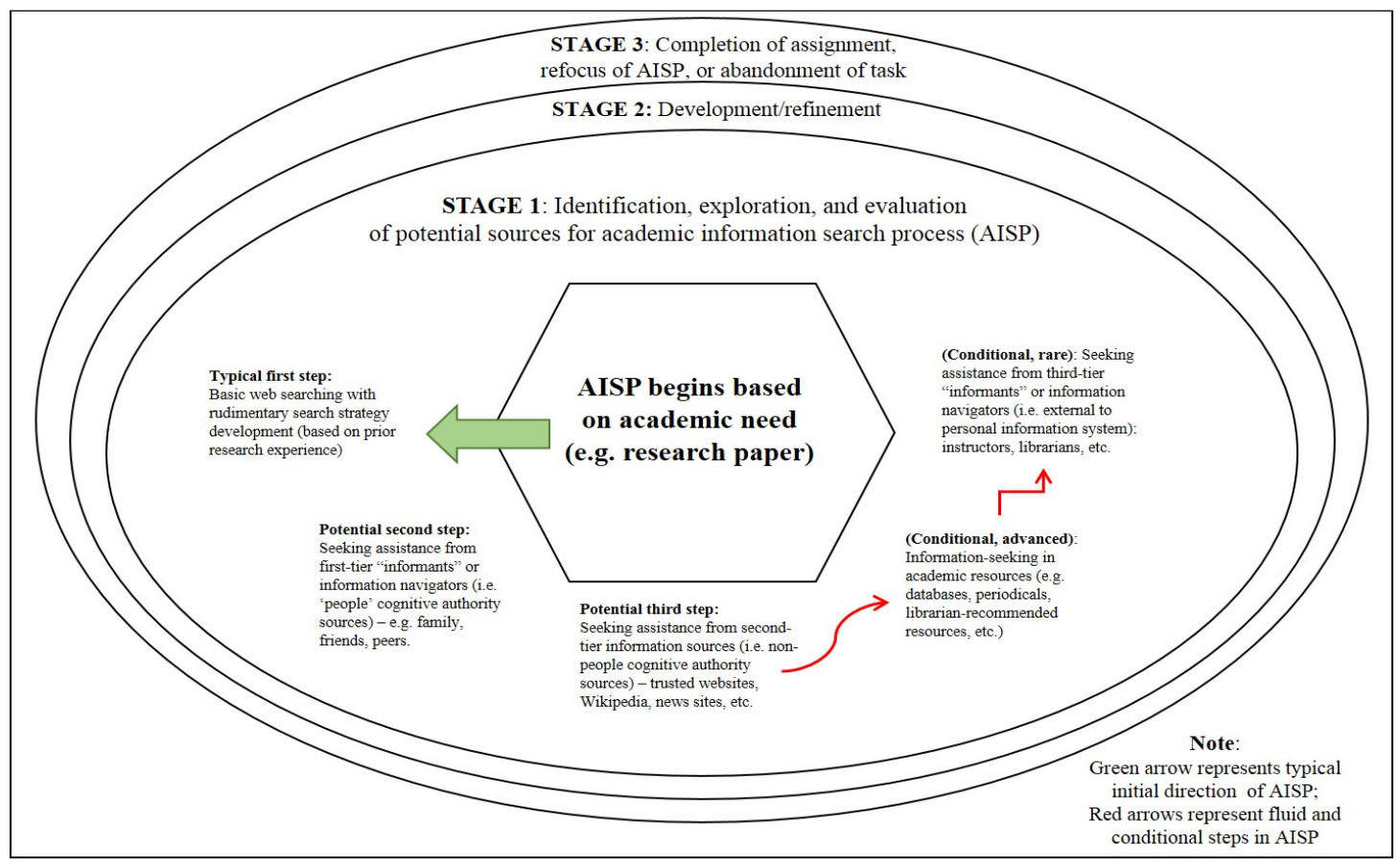

Stage 1 - Potential pitfalls and competing concerns:

Current information-seeking skills/information literacy abilities; Knowledge of academic resources vs. reliance on information-seeking in popular search engines exclusively; Cognitive authority sources, 'black and white' Personal Information Systems, Other class assignments; Competing work/family life roles; Placement in higher education structure; Attitude to research and higher education in general; Time.

\section{Stage 2: Factors/steps}

- Academic information search process (AISP) progresses and is refined/reshaped by the student based on information found during Stage 1.

- Anxiety at this stage ranges from mild to extreme, depending on the success of the student's AISP in finding information he/she believes is appropriate for addressing the academic need.

- At this point, the student may return to one, more, or all steps completed during their beginning AISP in Stage 1, based on their assessment of how well the information they have found meets the original academic need. 
Stage 3: Factors/steps

- Overall AISP evaluated by the student based on the success/failure of process itself in Stages $1 \& 2$.

- AISP confirmed/refuted by seeking additional assistance from instructors, librarians, and/or support services (writing centers, etc.).

- Based on information located through the AISP in Stages 1 \& 2, student either fulfills academic need with minimal anxiety, refocuses AISP with mid to high-level anxiety, or abandons the academic need completely with high/extreme levels of anxiety.

The methodology which framed my study and the methods used to collect data from my dissertation study participants are presented in the next section.

\section{Methodology and Methods for Documenting the Information-seeking Experience}

I chose to use descriptive phenomenology as the research frame for my dissertation study based on its focus on the essence of a shared experience, as described by participants in a study (Dowling, 2007; Englander, 2012; Giorgi, 1997; van Manen, 1990; Wojnar et al., 2007). As previously stated, there is very little research available on the information-seeking behaviors of remedial undergraduate students (who, as discussed earlier in this paper, are students who require remedial coursework before entering traditional higher education courses, and who are also more academically at-risk than their non-remedial undergraduate peers). Further, scholarly evidence supports the notion that information literacy skills are connected to academic progress (Boon et al., 2007; Salisbury et al., 2011). Therefore, I believe that in order to learn about the academic information search process of remedial undergraduate students; research engaging participants in deep reflective thought and which examines the commonalities of the shared AISP experience (rather than unique participant perspectives) must be conducted. Such research will create a solid foundation for further, broad-spectrum study into the information literacy abilities of remedial undergraduate students.

Although phenomenography (which examines the variance of participant perspectives in relation to a shared experience-Andretta, 2007) is a common method used to study information behavior in undergraduate students in library and information science research; it was the essence, or commonalities, of the shared AISP experience I wanted to understand and learn more about for my dissertation study. Descriptive phenomenology was therefore chosen as an appropriate methodology to uncover the essence of the shared AISP experience, and final analysis findings will be used to create a foundational model of the AISP 
experience of remedial undergraduate students, for the purpose of creating needsbased information literacy instruction for this group, and in developing assessment instruments which would measure the specific needs of these students on a much larger scale.

In order to gain a rich understanding of the shared AISP experience of my dissertation study participants (six students enrolled in a remedial English course at a regional campus of a 4-year, state university in Ohio, United States, in spring, 2014), triangulation of data sources was used in the study. This included one-onone interviews with participants, in-class observations of information literacy instruction (ILI), in-lab observations of academic information-seeking processes used by participants, and reading through participants' final research papers. For final data analysis, I will use an adapted version of Colaizzi's method of analysis (as described in Colaizzi, 1973, and Wojnar et al., 2007) to conduct final data analysis and draw out the essence of the shared AISP experience for the purposes of creating the model discussed previously. In concluding this section, the words of descriptive phenomenological researcher Giorgi (1997) are cited herein: "Phenomenology has had an impact on $20^{\text {th }}$ century thinking not only because of its rigorous descriptive approach but also because it offers a method for accessing the difficult phenomena of human experience" (p. 237). The academic information search process experience of remedial students is complex, and arguably more difficult than that of their non-remedial peers (defined as those students who are not required to take remedial coursework before entering a traditional higher education program of study). Therefore, using such a methodology to uncover even one facet of the academic lives of remedial undergraduate students may reveal previously unknown insights into their information-seeking behaviors, aiding the creation of targeted ILI for these students which addresses their specific needs and improves their long-term academic progress.

The next section shall discuss briefly the study findings I produced after primary analysis of collected data was conducted, which were shared during my presentation at DOCAM'14.

\section{Initial Findings from Primary Analysis of Collected Data}

Descriptive phenomenological study requires that analysis occur in numerous stages. This is done in order to eliminate researcher bias as much as possible and uncover the essence of a shared experience as gathered from triangulated data collection methods, analyzed at multiple stages in the study (Colaizzi, 1973; Giorgi, 1997; Wojnar et al., 2007). To that end, I conducted primary analysis of collected data by creating information profiles for each of the study's participants. 
These profiles included the information shared by participants during their oneon-one interviews, and from notes I took during in-class ILI and in-lab observation days. After reading these profiles multiple times, numerous elements were extracted from the documentation of this process. Primary analysis revealed that almost all participants in the study a) had taken and failed the course under observation in the previous academic semester (i.e. fall, 2013), b) believed their information literacy skills were, in general, above the norm of their peers, and c) believed that resources available to assist them in the course and with learning concepts such as information literacy development (e.g. the on-campus Writing Center, the on-campus library, etc.) were ineffective in providing them with the type of assistance they believed they needed to succeed in the course, based on their experiences with this course in the previous semester. Additionally, all participants in the study stated at least twice in their interviews that they were not motivated to learn in the course in which the study took place. Particularly, most participants noted they were unwilling to learn advanced AISP skills for academic research purposes, believing that their current knowledge of academic information-seeking practices was more than sufficient in helping them meet the course's research assignment requirements and the requirements of future academic assignments.

As stated previously, these elements represent only the primary analysis phase of my dissertation study. The next section shall outline next steps in the data analysis process, toward uncovering the essence of the participants' shared AISP experience and which will be reported in the results chapter of my dissertation.

\section{Next Steps in the Study}

As discussed previously, analysis of data collected during a descriptive phenomenological study is a multi-stage process, and includes a number of strategic methods to reduce the impact of researcher bias and supposition on the study as much as possible. Because analysis for this study needs to move the collected data from individual student perspectives to a unified representation of the essence or commonalities of the shared AISP experience; next steps in the study involve the implementation of these researcher role-addressing methods, as well as the secondary and final methods of analysis of collected data (and consequent creation of a model representing the essence of the study participants' shared experience).

Methods used to remove researcher bias and supposition from the study began before the study itself, and involved creating an 'epoche,' a documentation of my previous experiences with the phenomenon under investigation, as well as detailed reflections on prejudgments, biases, or preconceived ideas I may have 
had going into the study. Moustakas (1994) explains that creating an epoche prior to beginning a research study is a crucial aspect of descriptive phenomenology, in that it gives the researcher the ability to clear his or her mind of any elements which might skew what is seen in the research environment. Additionally, I used phenomenological reduction and bracketing methods (i.e. continual documentation of biases, skewed perceptions, and researcher observations during the study) throughout the study to keep my perspectives as separate as possible from actual observations within the study environment.

Secondary data analysis for this study involves horizonalization of all collected data: A process whereby all collected data elements are documented and assigned equal weight, and therefore are given equal consideration before moving data into the final analysis phase (Moustakas, 1994). Final data analysis involves the implementation of an adapted version of Colaizzi's method of analysis using the results of the secondary, horizonalized data analysis stage (Colaizzi, 1973; Wojnar et al., 2007). This includes "1) reading and rereading descriptions, 2) extracting significant statements, 3) formulating meanings, 4) categorizing into clusters of themes and validating with original text, [and] 5) describing" (Wojnar, 2007, p. 177).

Descriptions of the clusters of themes shall be representative of the essence of the shared AISP experience of study participants, and will be used to create a foundational model of this experience for use in future study, and in the creation of targeted, needs-based ILI modules. I plan to continue this line of inquiry in future research studies, including assessing the impact students believe such instruction has on their overall information literacy skill development and consequent academic progress.

\section{Conclusion of Proceedings Paper}

In concluding the presentation for DOCAM'14, I asked the audience to consider what they had heard and offer any feedback, insight, or perspectives that may help me in creating useful and meaningful learning objects after the study was complete, and in future information study with remedial undergraduate students. Eminent scholar in the field of Document Studies, Dr. Michael Buckland, suggested investigating the role of motivation in information behavior further, and explained how this investigation might lead to the creation of critical theory in this area that could be used by educators to improve the academic progress of remedial undergraduate students across the United States (personal communication, Michael Buckland, August 9, 2014). Additionally, others suggested further research involving information literacy considerations and remedial undergraduate students. Indeed, some attendees noted that they had 
often felt at a loss to fully address the needs of this student group because, quite simply, they don't understand fully what their needs are.

It is my firm intention to continue studying information needs, seeking, and information literacy behaviors of at-risk student populations, and I believe the results of the research study discussed herein (and which will be completed in early 2015) will create a solid foundation from which to move beyond, and further expand the boundaries of this underexplored area.

\section{References}

American Library Association. (2000). Information Literacy Competency Standards for Higher Education. Retrieved from http://www.ala.org/ala/mgrps/divs/acrl/standards/standards.pdf

Andretta, S. (2007). Phenomenography: A conceptual framework for information literacy education. ASLIB Proceedings: New Information Perspectives, 59, 152-168. DOI: 10.1108/00012530710736663

Bailey, T., Jaggars, S. S., \& Scott-Clayton, J. (2013). Characterizing the effectiveness of developmental education: A response to recent criticism. Community College Research Center, 2-16. Retrieved from http://www.delta.edu/files/DevEd/Research/response-to-goudas-andboylan.pdf

Bettinger, E. P., and Long, B. T. (2005, May). Addressing the needs of underprepared students in higher education: Does college remediation work? (NBER Working Paper 11325). Cambridge, MA: National Bureau of Economic Research.

Blundell, S., \& Lambert, F. (2014). Information anxiety from the undergraduate student perspective: A pilot study of second semester freshmen. Journal of Education in Library and Information Science, 55(4).

Buglear, J. (2009). Logging in and dropping out: Exploring student noncompletion in higher education using electronic footprint analysis. Journal of Further and Higher Education, 33, 381-393. DOI: 10.1080/03098770903272479.

Colaizzi, P. F. (1973). Reflection and research in psychology: A phenomenological study of learning. Dubuque, IA: Kendall/Hunt Publishing Company. 
DiTommaso, K. (2012). Developmental students: The challenge of peer relationships. Community College Journal of Research and Practice, 36, 941-954. DOI: 10.1080/10668920903299304.

Dowling, M. (2007). From Husserl to van Manen. A review of different phenomenological approaches. International Journal of Nursing Studies, 44, 131-142. DOI: 10.1016/j.ijnurstu.2005.11.026.

Englander, M. (2012). The interview: Data collection in in descriptive phenomenological human scientific research. Journal of Phenomenological Psychology, 43, 13-35. DOI: $10.1163 / 156916212 X 632943$.

Giorgi, A. (1997). The theory, practice, and evaluation of the phenomenological method as a qualitative research procedure. Journal of Phenomenological Psychology, 28, 235-260.

Gross, M., \& Latham, D. (2011). Experiences with and perceptions of information: A phenomenographic study of first-year college students. Library Quarterly, 81, 161-186. DOI: 0024-2519/2011/8102-0002

Gross, M., \& Latham, D. (2009). Undergraduate perceptions of information literacy: Defining, attaining, and self-assessing skills. College and Research Libraries, 70, 336-350.

Gross, M., \& Latham, D. (2007). Attaining information literacy: An investigation of the relationship between skill level, self-estimates of skill, and library anxiety. Library and Information Science Research, 29, 332-353. DOI: 10.1016/j.lisr.2007.04.012.

Gross, M. (2005). The impact of low-level skills on information-seeking behavior. Reference \& User Services Quarterly, 45, 155-63

Hamilton, D. W. (2013). Contextualized learning may redefine remedial education. Community College Journal of Research and Practice, 37, 1016-1020. DOI: 10.1080/10668926.2012.746209.

Head, A. J. (2013). How freshmen conduct course research once they enter college. Project Information Literacy Research Report: "Learning the Ropes." Retrieved from http://projectinfolit.org/pdfs/PIL_2013_FreshmenStudy_FullReport.pdf

Jerabek, J. A., Meyer, L. S., \& Kordinak, S. T. (2001). "Library anxiety" and "computer anxiety:" Measures, validity, and research implications. Library and Information Science Research, 23, 277-289. PII: S07408188(01)00083-4. 
Jiao, Q. G., \& Onwuegbuzie, A. J. (2004). The impact of information technology on library anxiety: The role of computer attitudes. Information Technology and Libraries, 23, 138-144.

Jiao, Q. G., Onwuegbuzie, A. J., \& Lichtenstein, A. A. (1996). Library anxiety: Characteristics of 'at-risk' college students. Library and Information Science Research, 18, 151-163. Retrieved from Library and Information Science Full-text Database.

Kalbach, J. (2006). "I'm feeling lucky:" The role of emotions in seeking information on the

Web. Journal of the American Society for Information Science and Technology, 57, 813-818. DOI: 10.1002/asi.20299

Kuhlthau, C. C. (1991). Inside the search process: Information seeking from the user's perspective. Journal of the American Society for Information Science, 42, 361-371.

Kwon, N. (2008). A mixed-methods investigation of the relationship between critical thinking and library anxiety among undergraduate students in their information search process. College \& Research Libraries, 69, 117-131.

Kwon, N., Onwuegbuzie, A. J., \& Alexander, L. (2007). Critical thinking disposition and library anxiety: Affective domains on the space of information seeking and use in academic libraries. College and Research Libraries, 68, 268-278.

Lee, S. W. (2012). An exploratory study of library anxiety in developmental education students. Community and Junior College Libraries, 18, 67-87. DOI: $10.1080 / 02763915.2012 .726806$

Malvasi, M., Rudowsky, C., \& Valencia, J. M. (2009). Library RX: Measuring and treating library anxiety, a research study. Chicago, IL: Association of College and Research Libraries.

Moustakas, C. (1994). Phenomenological research methods. Thousand Oaks, CA: Sage Publications, Inc.

Mulvey, M. E. (2009). Characteristics of under-prepared students: Who are the "under-prepared?" Research and Teaching in Developmental Education, 25, 29-58.

Nahl, D., \& Bilal, D. (Eds.). (2007). Information and emotion: The emergent affective paradigm in information behavior research and theory. Medford, NJ: American Society for Information Science and Technology. 
Nicholas, D., Huntington, P., Jamali, H. R., Rowlands, I., \& Fieldhouse, M. (2009). Student digital information-seeking behavior in context. Journal of Documentation, 65, 106-132. DOI: 10.1108/00220410910926149.

O'Brien, H., \& Symons, S. (2007). The information behaviors and preferences of undergraduate students. Research Strategies, 20, 409-423.

Onwuegbuzie, A. J., Jiao, Q. G., \& Bostick, S. L. (2004). Library Anxiety: Theory, research, and applications. Lanham, MD: Scarecrow Press, Inc.

Parker, S. (2012). From roadblock to gateway: Improving developmental education for student success. Grantmakers for Education. Retrieved from http://files.eric.ed.gov/fulltext/ED537486.pdf

Prabha, C., Connaway, L. S., Olszewski, L., \& Jenkins, L. R. (2007). What is enough? Satisficing information needs. Journal of Documentation, 63, 7489.

Retrieved

from

http://www.oclc.org/research/publications/archive/2007/prabhasatisficing.pdf

Project Information Literacy (2012). How college students find and use information. Retrieved from http://blog.reyjunco.com/how-collegestudents-find-and-use-information-infographic

Roselle, A. (2009). Preparing the underprepared: Current academic library practices in developmental education. College and Research Libraries, 70, 142-156.

Salisbury, F., \& Karasmanis, S. (2011). Are they ready? Exploring student information literacy skills in the transition from secondary to tertiary education. Australian Academic \& Research Libraries, 42, 43-58.

Sparks, D., \& Malkus, N. (2013). Statistics in brief: First-year undergraduate remedial coursetaking: 1999-2000, 2003-04, 2007-08. National Center for Education Statistics, January, 1-12.

Van Kampen, D. J. (2004). Development and validation of the multidimensional library anxiety scale. College and Research Libraries, 65, 28-34.

Van Manen, M. (1990). Researching lived experience: Human science for an action sensitive pedagogy. London, Ontario: State University of New York Press.

Vitasari, P., Wahab, M. N. A., Othman, A., \& Awang, M. G. (2010). A research for identifying study anxiety sources among university students. International Education Studies, 3, 189-196. 
Wojnar, D. M., \& Swanson, K. M. (2007). Phenomenology: An exploration. Journal of Holistic Nursing, 25, 172-180. DOI: $10.1177 / 0898010106295172$. 